\title{
Cloning and characterization of the gene encoding ribosomal P0 phosphoprotein from Neurospora crassa
}

\author{
Dawid Krokowski, Marek Tchórzewski and Nikodem Grankowski ${ }^{\bowtie}$ \\ Maria Curie-Skłodowska University, Institute of Microbiology and Biotechnology, Department of \\ Molecular Biology, Lublin, Poland
}

Received: 13 November, 2001; revised: 4 February, 2002; accepted: 27 February, 2002

Key words: Neurospora crassa, cloning, ribosomal P0 protein, phosphorylation

\begin{abstract}
A gene for ribosomal protein $\mathrm{P0}$ that belongs to the family of ribosomal $\mathrm{P}$ proteins was isolated from a Neurospora crassa cDNA library, using polyclonal antibodies against recombinant $\mathrm{P0}$ protein from Saccharomyces cerevisiae. This is the first gene for ribosomal $\mathrm{P0}$ protein to be cloned from filamentous fungi. The derived P0 protein sequence has a strong homology to other eukaryotic P0 proteins; yet, there is a notable alteration in the conservative $\mathrm{C}$-terminal region, placing this protein among the unique sequences from protozoan parasites.
\end{abstract}

The eukaryotic ribosomal "stalk" consists of a single ribosomal core $\mathrm{P} 0$ protein and strongly acidic $\mathrm{P}$ proteins. The $\mathrm{P} 0$ protein plays an essential role by docking the whole "stalk" complex to 26/28S rRNA through the N-terminal domain, while the C-terminal domain interacts with the $\mathrm{P} 1$ and $\mathrm{P} 2$ proteins, forming the tip of the "stalk" [1]. A unique feature of $\mathrm{P}$ proteins is the presence of an intriguing C-terminal fragment, which is extremely well preserved in all eukaryotic organisms from yeast to humans [2], containing a serine residue that is phosphorylated by several protein kinases [3]. In yeast cells the P0 protein is absolutely required for cell viability [4]. This protein is considered as a minimal "stalk" particle sufficient to support by itself ribosome activity, but at a lower rate than the complete "stalk". In contrast, the P1 and P2 proteins from yeast cells are not absolutely required for ribosome activity and cell viability [5]. On the other hand, the eukaryotic "stalk" is implicated in an interaction with elongation factor 2 (EF2) [6].

\footnotetext{
${ }_{\text {This work was partly supported by the State Committee for Scientific Research (KBN, Poland) Grant }}$ No. 6P04A 05021 to N.G.

${ }^{\otimes}$ Corresponding author: Nikodem Grankowski, Maria Curie-Skłodowska University, Institute of Microbiology and Biotechnology, Department of Molecular Biology, Akademicka 19, 20-033 Lublin, Poland; phone: (48 81) 537 5950, fax: (48 81) 5375907 or (48 81) 537 5959;

e-mail: officeps@biotop.umcs.lublin.pl
} 
The P0 protein from Drosophila ribosomes exhibits apurinic/apyrimidinic endonuclease activity and might be involved in DNA repair [7]. Additionally, a potential involvement of the $\mathrm{P} 0$ protein in modifying gene expression pattern was also described [8]. The P0 protein has also been recognized as one of the autoantigens in the autoimmune disease systemic lupus erythematosus (SLE). The anti-P immunodominant epitope is the single sequential epitope contained within the conserved 22 amino-acid C-terminal peptide shared by $\mathrm{P}$ proteins, including the $\mathrm{P} 0$ protein [9]. In addition, this epitope plays an important role in infections caused by an intracellular protozoan parasite [10], and may also play a significant role in fungal allergy [11].

Since there is little information on ribosomal P proteins from filamentous fungi, we have cloned a gene coding for the $\mathrm{P} 0$ ribosomal protein from Neurospora crassa. To our knowledge, this is the ninth gene for a ribosomal protein from this organism to be identified and described so far [12].

\section{MATERIALS AND METHODS}

Materials and strains. Restriction endonucleases and DNA-modifying enzymes were purchased from MBI Fermentas. Pwo polymerase was from Roche. QIAquick purification kit was obtained from Qiagen. Escherichia coli $\mathrm{DH} 5 \alpha$ was used as host strain for all plasmid manipulations. Cells were grown in LB medium (1\% peptone, $0.5 \%$ yeast extract and $1 \% \mathrm{NaCl}$ ). E. coli cells BL21(DE3) (Novagen Inc.) were used for expression. Neurospora crassa, obtained from the strains collection of the Department of Industrial Microbiology, Maria Curie-Skłodowska University, was cultivated in YPD medium ( $2 \%$ peptone, $1 \%$ yeast extract and $2 \%$ dextrose) at $30^{\circ} \mathrm{C}$.

Manipulation of DNA. DNA was manipulated by standard methods as described by
Sambrook et al. [13]. DNA sequencing was performed using an ABI Prism 377 DNA sequencer with the ABI Prism BigDye terminator cycle sequencing kit (Applied Biosystems). Southern blotting was performed according to a standard procedure [13], with the DNA probe prepared using the PCR DIG probe synthesis kit (Roche). Positive signals were analyzed with the DIG nucleic acid detection kit (Roche). Genomic DNA of Neurospora crassa was prepared according to the procedure described earlier [14].

cDNA library screening. Anti-sera against the P0 protein from Saccharomyces cerevisiae were obtained by immunizing a rabbit with the recombinant protein overexpressed in $E$. coli as described before [4].

The cDNA library M-1 prepared from $N$. crassa mycelia in AZapII phage was obtained from the Fungal Genetic Stock Center (University of Kansas, Medical Center, U.S.A.). About 400000 recombinant plaques were screened with rabbit polyclonal antiserum against the $S$. cerevisiae recombinant $\mathrm{P} 0$ protein, utilizing the picoBlue immunoscreening kit with goat anti-rabbit serum (Stratagene), according to the manufacturer's instructions.

PCR amplification of genomic DNA. The $N$. crassa gene encoding the P0 protein was amplified by PCR from genomic DNA. The reaction was performed with the following oligonucleotide primers: forward primer $-5^{\prime}$ CAA ATT AAA CAA GAG AAC TC 3'; reverse primer - 5' GAA GTT AGT TCT AGT CAG AGA GAC ATT TAG 3'. Pwo polymerase was used for amplification because of its $3^{\prime}-5^{\prime}$ exonuclease activity, also known as proofreading activity. Experimental conditions were as follows: $95^{\circ} \mathrm{C}-60 \mathrm{~s}, 56^{\circ} \mathrm{C}-30 \mathrm{~s}, 72^{\circ} \mathrm{C}-90 \mathrm{~s}, 30$ cycles. The resulting PCR product was purified using the QIAquick PCR purification kit (Qiagen) and subcloned into the pUC19 vector.

Expression of the Neurospora crassa PO protein. cDNA was PCR amplified with the following oligonucleotide primers: forward primer $-5^{\prime}$ CAG GAG AAT AAC AAT GGG 
GGG CAA GTC 3'; reverse primer - 5' GCT ATAA ATA ATT CAT GTT GCA CTT CTT AAT $3{ }^{\prime}$. The forward primer introduced a ribosomal binding site as the fragment of Shine-Dalgarno sequence (embolded) in the non-coding upstream region. For PCR reaction $P w o$ polymerase was used with the following program: $95^{\circ} \mathrm{C}-60 \mathrm{~s}, 56^{\circ} \mathrm{C}-15 \mathrm{~s}$, $72^{\circ} \mathrm{C}-90 \mathrm{~s}, 25$ cycles. The resulting bluntended PCR product was subcloned into the pLM1 plasmid [15] using the SmaI site, giving the pLM-P0NcEx construct. The construct was verified by restriction enzyme analysis and DNA sequencing. Expression of the P0 protein was performed in $E$. coli BL21(DE3) according to the procedure described for other acidic ribosomal $\mathrm{P}$ proteins [16]. Inclusion bodies were solubilized in a buffer containing $8 \mathrm{M}$ urea and $50 \mathrm{mM}$ Tris/HCl, pH 7.8. Subsequently, the protein solution was diluted 25 times with a buffer containing $50 \mathrm{mM}$ Tris/ $\mathrm{HCl}, \mathrm{pH} 7.8,150 \mathrm{mM}$ $\mathrm{NaCl}, 5 \mathrm{mM} \mathrm{MgCl}_{2}$, and dialyzed against the same buffer. A small portion of the recombi- tein kinase CK2 isolated from yeast cells as described previously [3]. Ribosomes of $N$. crassa were prepared by grinding the mycelia with a pre-cooled mortar and pestle under liquid nitrogen. Details of the preparation were described earlier [3]. Computer analysis of DNA and protein sequences was carried out using the BLAST [18] and ClustalW [19] programs.

\section{RESULTS AND DISCUSSION}

\section{Cloning and DNA sequencing of the $N$. crassa crpPO gene for the $\mathrm{PO}$ protein}

In order to clone the gene encoding the ribosomal protein P0 from $N$. crassa, we used polyclonal antibodies against the P0 protein from $S$. cerevisiae that recognize the P0 protein from $N$. crassa as well (Fig. 1A). Twelve positive clones were identified after the third round of the immuno-screening procedure. All of them were converted by in vivo excision

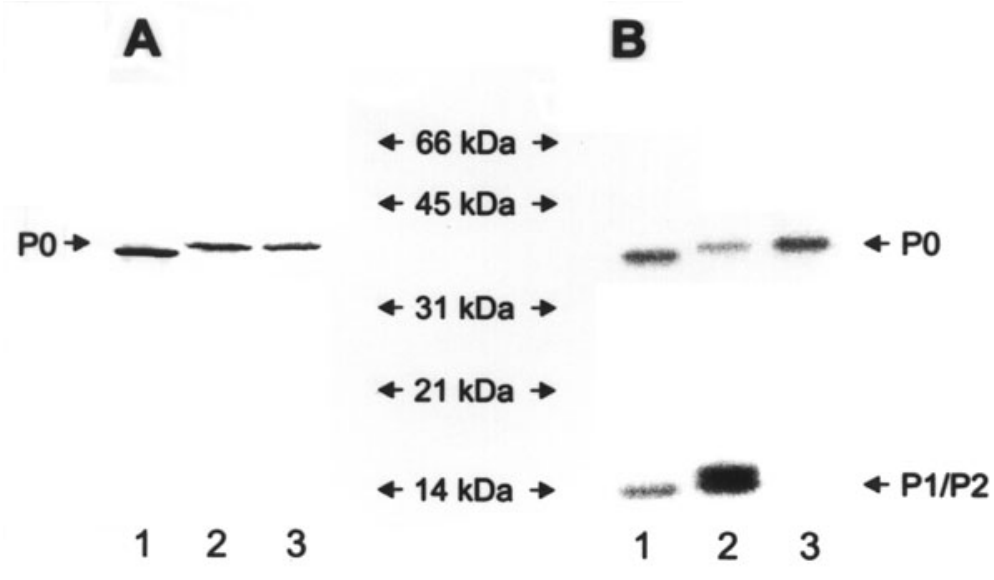

Figure 1. Identification of P0 proteins by: A. Immunoblotting; B. Autoradiography after phosphorylation by protein kinase CK2.

1, Ribosomes from $S$. cerevisiae strain W303 (30 $\mu \mathrm{g})$; 2, ribosomes from $N$. crassa $(30 \mu \mathrm{g}) ; 3$, inclusion bodies containing recombinant P0 protein from $N$. crassa $(5 \mu \mathrm{g})$.

nant $\mathrm{P} 0$ protein remaining in solution was used for further analysis.

Other methods. SDS/polyacrylamide gel electrophoresis (SDS/PAGE) was performed according to Laemmli's method in 14\% acrylamide slab gels [17]. Protein bands were visualized by staining with Coomassie Brilliant Blue R-250. Western blotting analysis was performed as described earlier [1]. Phosphorylation was carried out using pro- procedure, from phage into pBluescript plasmid containing cDNA, and then sequenced. The resulting DNA sequences were further used to search for homology in the GenBank database. Out of the twelve clones nine had a significant homology to the ribosomal $\mathrm{P} 0$ proteins genes from various species. Multiple alignment showed that only four clones had an intact open reading frame. All four clones were sequenced from both ends, 
and that with the longest DNA sequence (crpP0) was chosen for further analysis. The full nucleotide sequence of the crpPO gene is shown in Fig. 2. It was interesting to know whether the $\operatorname{crpPO}$ gene was divided by intron sequences, as all ribosomal protein genes cloned so far from $N$. crassa possess one or two interrupting sequences. Thus, the genomic copy of the crpPO gene was PCR amplified from $N$. crassa genomic DNA and subsequently sequenced. A comparison of the cDNA and genomic sequences revealed the presence of two introns in the crpPO gene. The first one is located $176 \mathrm{bp}$ from the ATG start codon and the second one at the very end of the gene, $1001 \mathrm{bp}$ from the ATG codon. The

\begin{tabular}{|c|c|c|c|c|c|c|c|c|c|c|c|c|c|c|c|}
\hline \multirow[b]{2}{*}{1} & \multirow{2}{*}{\multicolumn{4}{|c|}{ gtgctaaaagaagat }} & \multirow{3}{*}{$\begin{array}{c}\text { atg } \\
\mathrm{M} \\
\text { aag }\end{array}$} & \multirow{3}{*}{$\begin{array}{c}\operatorname{ggg} \\
\mathrm{G} \\
\operatorname{ggc}\end{array}$} & \multirow{3}{*}{$\begin{array}{c}\text { ggc } \\
\text { ttg }\end{array}$} & \multirow{3}{*}{$\begin{array}{c}\text { aag } \\
\mathrm{K} \\
\mathrm{ttg}\end{array}$} & \multirow{3}{*}{$\begin{array}{c}\text { tct } \\
\text { S } \\
\text { gag }\end{array}$} & \multirow{3}{*}{$\begin{array}{c}\text { get } \\
\text { A } \\
\text { gat }\end{array}$} & \multirow{3}{*}{$\begin{array}{c}\mathrm{aac} \\
\mathrm{N} \\
\mathrm{tac}\end{array}$} & \multirow{3}{*}{$\begin{array}{c}\text { aag } \\
\mathrm{K} \\
\mathrm{cgg}\end{array}$} & \multirow{3}{*}{$\begin{array}{c}\mathrm{gcc} \\
\mathrm{A} \\
\text { tcc }\end{array}$} & \multirow{3}{*}{$\begin{array}{c}\text { ggt } \\
\text { atc }\end{array}$} & \multirow{3}{*}{$\begin{array}{c}\operatorname{tac} \\
\mathrm{Y} \\
\mathrm{ttc}\end{array}$} \\
\hline & & & & & & & & & & & & & & & \\
\hline & $\mathrm{ttc}$ & gac & aag & $\operatorname{ctg}$ & & & & & & & & & & & \\
\hline \multirow[t]{2}{*}{12} & $\mathrm{~F}$ & $\mathrm{D}$ & $\mathrm{K}$ & $\mathrm{L}$ & $\mathrm{K}$ & $\mathrm{G}$ & $\mathrm{L}$ & $\mathrm{L}$ & $\mathrm{E}$ & $\mathrm{D}$ & $\mathrm{Y}$ & $\mathrm{R}$ & $S$ & I & \\
\hline & atc & gtc & tcc & gtc & gac & aat & gtc & agc & tct & cag & cag & atg & $\mathrm{cac}$ & gag & t \\
\hline \multirow[t]{2}{*}{27} & I & V & $\mathrm{S}$ & V & $\mathrm{D}$ & $\mathrm{N}$ & V & $S$ & $S$ & $\mathrm{Q}$ & $\mathrm{Q}$ & $\mathbf{M}$ & $\mathrm{H}$ & $\mathrm{E}$ & \\
\hline & aga & cag & tcc & ctc & $\operatorname{cgc}$ & ggt & gag & gct & gtc & gtc & $\operatorname{ttg}$ & atg & $\mathrm{ggc}$ & aag & \\
\hline \multirow[t]{2}{*}{42} & $\mathrm{R}$ & $\mathrm{Q}$ & $\mathrm{S}$ & L & $\mathrm{R}$ & $\mathrm{G}$ & $\mathrm{E}$ & A & V & V & $\mathrm{L}$ & $\mathbf{M}$ & $\mathrm{G}$ & $\mathrm{K}$ & $\mathrm{N}$ \\
\hline & acc & atg/ & gta & $\operatorname{gttg}$ & cgttg & cgca & gaga & $\operatorname{tcgc}$ & cttc & ggaa & geccas & gaaatt & aacac & ccatta & acag \\
\hline \multirow[t]{2}{*}{57} & $\mathrm{~T}$ & $\mathrm{M}$ & & & & & & & & & & & & & \\
\hline & $/ g t t$ & $\operatorname{cgc}$ & cgt & gec & ctc & aag & acc & $\mathrm{ttc}$ & gtc & gec & gac & acc & $\mathrm{ccc}$ & gag & $\operatorname{tac}$ \\
\hline \multirow[t]{2}{*}{59} & $\mathrm{~V}$ & $\mathrm{R}$ & $\mathrm{R}$ & A & $\mathrm{L}$ & $\mathrm{K}$ & $\mathrm{T}$ & $\mathrm{F}$ & V & $\mathrm{A}$ & $\mathrm{D}$ & $\mathrm{T}$ & $\mathrm{P}$ & $\mathrm{E}$ & \\
\hline & gag & $\operatorname{cgt}$ & ctc & ctc & $\mathrm{ccc}$ & ttc & gac & aag & ggc & aac & gtt & ggt & ttc & gtc & tc \\
\hline \multirow[t]{2}{*}{74} & $\mathrm{E}$ & $\mathrm{R}$ & $\mathrm{L}$ & $\mathrm{L}$ & $\mathrm{P}$ & $\mathrm{F}$ & V & $\mathrm{K}$ & $\mathrm{G}$ & $\mathrm{N}$ & V & G & $\mathrm{F}$ & V & \\
\hline & $\mathrm{acc}$ & aac & ggc & gac & ctc & aag & gag & gtc & cgt & gac & aag & atc & ctc & $\mathrm{gcc}$ & aac \\
\hline 89 & $\mathrm{~T}$ & $\mathrm{~N}$ & $\mathrm{G}$ & D & $\mathrm{L}$ & $\mathrm{K}$ & $\mathrm{E}$ & V & $\mathrm{R}$ & $\mathrm{D}$ & $\mathrm{K}$ & I & $\mathrm{L}$ & A & \\
\hline & aag & gtc & get & gcc & $\operatorname{ccc}$ & get & $\operatorname{cgt}$ & $\mathrm{gcc}$ & ggt & gcc & atc & gcc & cct & gcc & gat \\
\hline 104 & $\mathrm{~K}$ & $\mathrm{~V}$ & A & A & $\mathrm{P}$ & A & $\mathrm{R}$ & A & $\mathrm{G}$ & A & I & A & $\mathrm{P}$ & $\mathrm{A}$ & \\
\hline & gtc & $\operatorname{tgg}$ & atc & $\mathrm{ccc}$ & gct & ggc & aac & acc & ggt & atg & gaa & $\mathrm{ccc}$ & ggc & aag & acc \\
\hline 119 & V & W & I & $\mathrm{P}$ & A & $\mathrm{G}$ & $\mathrm{N}$ & $\mathrm{T}$ & $\mathrm{G}$ & $\mathrm{M}$ & $\mathrm{E}$ & $\mathrm{P}$ & $\mathrm{G}$ & $\mathrm{K}$ & \\
\hline & tct & $\mathrm{ttc}$ & $\mathrm{ttc}$ & cag & $\mathrm{gcc}$ & ctc & ggt & gtc & $\operatorname{ccc}$ & acc & aag & atc & $\mathrm{gcc}$ & cgt & ggt \\
\hline 134 & S & $\mathrm{F}$ & $\mathrm{F}$ & $\mathrm{Q}$ & $\mathrm{A}$ & L & $\mathrm{G}$ & V & $\mathrm{P}$ & $\mathrm{T}$ & $\mathrm{K}$ & I & $\mathrm{A}$ & $\mathrm{R}$ & $\mathcal{G}$ \\
\hline & acc & att & gaa & atc & acc & acc & gat & $\mathrm{ctc}$ & aag & ctc & $\mathrm{gtt}$ & gag & get & ggc & $\mathrm{gcc}$ \\
\hline 149 & $\mathrm{~T}$ & I & $\mathrm{E}$ & I & $\mathrm{T}$ & $\mathrm{T}$ & $\mathrm{D}$ & $\mathrm{L}$ & $\mathrm{K}$ & $\mathrm{L}$ & V & $\mathrm{E}$ & $\mathrm{A}$ & $\mathrm{G}$ & 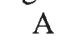 \\
\hline & aag & gtc & ggc & $\mathrm{ccc}$ & tct & gag & gct & acc & ctg & $\operatorname{ttg}$ & aac & atg & ctc & aac & ttc \\
\hline 164 & K & $\mathrm{V}$ & $\mathrm{G}$ & $\mathrm{P}$ & $S$ & $\mathrm{E}$ & $\mathrm{A}$ & $\mathrm{T}$ & L & $\mathrm{L}$ & $\mathrm{N}$ & M & $\mathrm{L}$ & $\mathrm{N}$ & \\
\hline & tct & $\operatorname{ccc}$ & $\mathrm{ttc}$ & acc & tac & ggt & atg & ggc & atc & gct & cag & gtc & tac & gac & a \\
\hline 179 & $S$ & $\mathrm{P}$ & $\mathrm{F}$ & $\mathrm{T}$ & $\mathrm{Y}$ & $\mathrm{G}$ & $\mathrm{M}$ & $\mathrm{G}$ & I & A & $Q$ & V & $\mathrm{Y}$ & $\mathrm{D}$ & \\
\hline & ggc & $\mathrm{aac}$ & acc & $\mathrm{ttc}$ & $\mathrm{ccc}$ & tcc & gat & gtc & $\mathrm{ctt}$ & gac & atc & tct & gag & gag & cas \\
\hline 164 & $\mathrm{G}$ & $\mathrm{N}$ & $\mathrm{T}$ & $\mathrm{F}$ & $\mathbf{P}$ & $\mathrm{S}$ & D & V & $\mathrm{L}$ & $\mathrm{D}$ & I & $S$ & $\mathrm{E}$ & $\mathrm{E}$ & \\
\hline & ctc & ctc & aag & $\mathrm{gct}$ & $\mathrm{ttc}$ & tcc & act & $\mathrm{gcc}$ & atc & $\mathrm{acc}$ & acc & att & gcc & agc & ctc \\
\hline 209 & $\mathrm{~L}$ & $\mathrm{~L}$ & $\mathrm{~K}$ & A & $\mathrm{F}$ & $\mathrm{S}$ & $\mathrm{T}$ & A & I & $\mathrm{T}$ & $\mathrm{T}$ & I & $\mathrm{A}$ & $S$ & \\
\hline & $\operatorname{tcg}$ & ctc & gct & ctc & $\mathrm{aac}$ & $\mathrm{ttc}$ & $\operatorname{ccc}$ & act & $\mathrm{ctt}$ & $\operatorname{ccc}$ & tcc & gtc & atc & $\mathrm{cac}$ & \\
\hline 224 & $S$ & $\mathrm{~L}$ & A & $\mathrm{L}$ & $\mathrm{N}$ & $\mathrm{F}$ & $\mathrm{P}$ & $\mathrm{T}$ & $\mathrm{L}$ & $\mathrm{P}$ & $S$ & $\mathrm{~V}$ & I & $\mathrm{H}$ & \\
\hline & gtc & gtc & aac & $\mathrm{gcc}$ & tac & aag & aag & $\mathrm{gtt}$ & ctt & $\mathrm{gcc}$ & gtc & get & atc & gag & acc \\
\hline 239 & V & V & $\mathrm{N}$ & $\mathrm{A}$ & $\mathrm{Y}$ & $\mathrm{K}$ & $\mathrm{K}$ & V & $\mathrm{L}$ & A & $\mathrm{V}$ & A & I & $\mathrm{E}$ & T \\
\hline & gag & atc & agc & $\operatorname{tgg}$ & $\operatorname{ccc}$ & gag & atc & gag & gag & ctc & aag & gat & $\operatorname{cgc}$ & att & $\mathrm{gcc}$ \\
\hline 254 & E & I & $S$ & W & $\mathrm{P}$ & $\mathrm{E}$ & I & E & $\mathrm{E}$ & $\mathrm{L}$ & $\mathrm{K}$ & D & $\mathrm{R}$ & I & A \\
\hline & $\mathrm{aac}$ & $\mathrm{ccc}$ & gag & get & tat & gct & tcc & gcc & gct & $\mathrm{ccc}$ & gcc & gct & tcc & acc & gag \\
\hline 269 & $\mathrm{~N}$ & $\mathrm{P}$ & $\mathrm{E}$ & A & $Y$ & A & $\mathrm{S}$ & $\mathrm{A}$ & A & $\mathrm{P}$ & A & A & $\mathrm{S}$ & $\mathrm{T}$ & \\
\hline & get & gcc & cct & $\mathrm{gcc}$ & gct & ggc & aag & gcc & gag & gag & aag & gag & gag & gag & aas \\
\hline 284 & A & A & $\mathrm{P}$ & A & A & $\mathrm{G}$ & $\mathrm{K}$ & A & $\mathrm{E}$ & $\mathrm{E}$ & $\mathrm{K}$ & $\mathrm{E}$ & $\mathrm{E}$ & $\mathrm{E}$ & \\
\hline & gag & gag & tct & gat & gag & gat & gat & ggc & ggc & $\mathrm{ttc}$ & ggc & ggt & $\mathrm{ctc}$ & $\mathrm{tt} /$ & gtg \\
\hline 299 & $\mathrm{E}$ & E & $S$ & $\mathrm{D}$ & $\mathrm{E}$ & D & $\mathrm{D}$ & $\mathrm{G}$ & $\mathrm{G}$ & $\mathrm{F}$ & $\mathrm{G}$ & $\mathrm{G}$ & $\mathrm{L}$ & $\mathrm{F}$ & \\
\hline & & & & & & & & & & & /c & $\begin{array}{c}\text { gac } \\
\text { D }\end{array}$ & taa & & \\
\hline
\end{tabular}

Figure 2. DNA sequence and translated amino-acid sequence for P0 protein from N. crasa.

Slashes indicate intron boundaries. Potential polyadenylation signal is underlined.

GeneBank accesion No. AF361225, AF361226. 
boundary sequences of the inferred introns matched the consensus sequences for fungi [20].

In eukaryotes the copy numbers of ribosomal protein genes are known to vary. For example, most of the r-protein genes of S. cerevisiae have two copies [21]; however, out of eight $N$. crassa r-protein genes identified to-data five have only one copy and there is no information on the copy numbers of the three remaining genes. In order to determine the copy number of the crpPO gene Southern blotting was performed. An analysis of genomic DNA digested with EcoRI and HindIII, using the cDNA as a probe, gave only one band indicating that the crpPO gene existed in a single copy per haploid genome (data not shown).

\section{Structural features of the crpPO encoded protein}

The $\operatorname{crpPO}$ gene encodes a protein containing 313 amino acids, with a predicted molecular mass 33533 Da. However, the molecular mass of native P0 protein analyzed by SDS/PAGE is around $37 \mathrm{kDa}$ (Fig. 1A). The discrepancy between the predicted and analyzed molecular masses is probably related to the $\mathrm{pI}$ of the $\mathrm{P} 0$ protein, which is acidic (predicted pI 4.75), and may thence have an effect on protein migration in the gel as shown in the case of $\mathrm{P}$ proteins from $S$. cerevisiae [4]. A database search using the BLAST program revealed a high homology of the $N$. crassa P0 protein to P0 proteins from various species. The pairwise alignment with several sequences of the P0 protein from: $S$. cerevisiae (accession No. NP_013444), S. pombe (CAA21428), human (Pי5388), C. elegans (Q93572), D. melanogaster (P19889), A. thaliana (AAB95286), D. discoideum (P22685), T. cruzi (P26796) yielded identities 65\%, 59\%, 55\%, $54 \%, 52 \%, 45 \%, 42 \%$, and $37 \%$, respectively.

The overall structure of the $N$. crassa P0 protein follows closely that described for other eukaryotic P0 proteins. In the primary struc- ture three functional domains may be recognized. The rRNA-binding domain is located in the N-terminal part of the polypeptide chain and comprises about 200 amino acids. In a multiple alignment of several $\mathrm{P} 0$ sequences (Fig. 3), it can be recognized as two clusters of amino acids showing a high degree of conservation. This domain might be implicated in the interaction of the $\mathrm{P} 0$ protein with rRNA GTPase center [1]. The second functional region of the $\mathrm{P} 0$ protein located between amino acids 200 and 280 has a high homology in the primary structure to acidic ribosomal $\mathrm{P}$ proteins, and is responsible for the interaction with P1/P2 proteins [22]. As shown in Fig. 3, this region has evolved significantly in diverse organisms what has also been suggested by comparing different capacity of the heterologous $\mathrm{P} 0$ to bind yeast $\mathrm{P}$ proteins in vivo [1]. The third functional region that may be recognized in the $N$. crassa $\mathrm{P} 0$ protein is implicated in the interactions with elongation factors during translation [6]. This domain is placed in the C-terminal part of the polypeptide and comprises an alanine-rich hinge and the highly conserved sequence EESDDDMGFGLFD. Still, the $N$. crassa P0 protein has several alterations in the C-terminal domain. There are two insertions of glutamic acid and glycine and one methionine to glycine substitution (see Fig. 3). These changes place the $N$. crassa P0 protein among unique polypeptides with altered C-terminal part which belong to the group of the sequences from protozoan parasites.

\section{Heterologous expression of the crpPO gene}

In order to overproduce the $N$. crassa $\mathrm{P} 0$ protein, cDNA was PCR amplified, with simultaneous incorporation into the $5^{\prime}$ upstream non-coding region of a ribosomal binding site, the Shine-Dalgarno sequence, to ensure correct initiation of translation in $E$. coli cells. The DNA was subcloned into the pLM1 vector, where gene expression is driven by a 
strong $\mathrm{T} 7$ promoter, and induced by addition of IPTG. The recombinant $E$. coli cells carrying the pLM-P0NcEx plasmid produced the P0 protein, though most of the protein was located in inclusion-bodies. The molecular mass of the recombinant protein was identical with that of wild-type protein, as determined by Western blotting analysis (Fig. 1A). Since P0 proteins from several species can be phosphorylated in vitro by protein kinase CK2 [3], it was interesting to check whether P0 from $N$. crassa could also be phosphorylated by this enzyme. To investigate this possibility, native ribosomes from $N$. crassa were CK2-phosphorylated, which was visualized on an autoradiogram as two major bands corresponding to the $\mathrm{P} 0$ and $\mathrm{P} 1 / \mathrm{P} 2$ proteins (Fig.1B). After solubilization the recombinant P0 protein was also phosphorylated by CK2, indicating that it corresponded to the wild type.

\section{R E F R E R E N C E S}

1. Rodriguez-Gabriel, M.A., Remacha, M. \& Ballesta, J.P. (2000) The RNA interacting domain but not the protein interacting domain is highly conserved in ribosomal protein P0. J. Biol. Chem. 275, 2130-2136.

2. Shimmin, L.C., Ramirez, C., Matheson, A.T. \& Dennis, P.P. (1989) Sequence alignment and evolutionary comparison of the L10 equivalent and L12 equivalent ribosomal proteins from archaebacteria, eubacteria, and eucaryotes. J. Mol. Evol. 29, 448-462.

3. Boguszewska, A., Szyszka, R. \& Grankowski, N. (1997) The phosphorylation sites of ribo- somal P proteins from $S$. cerevisiae cells by endogenous CK-2, PK60S and RAP protein kinases. Acta Biochim. Polon. 44, 191-200.

4. Santos, C. \& Ballesta, J.P. (1994) Ribosomal protein P0, contrary to phosphoproteins P1 and $\mathrm{P} 2$, is required for ribosome activity and Saccharomyces cerevisiae viability. J. Biol. Chem. 269, 15689-15696.

5. Remacha, M., Santos, C. \& Ballesta, J.P. (1995) Disruption of single-copy genes encoding acidic ribosomal proteins in Saccharomyces cerevisiae. Mol. Cell. Biol. 10, 21822190.

6. Uchiumi, T., Kikuchi, M., Terao, K., Iwasaki, K.N. \& Ogata, K. (1986) Cross-linking of elongation factor 2 to rat-liver ribosomal proteins by 2-iminothiolane. Eur. J. Biochem. 156, $37-48$.

7. Grabowski, D.T., Deutsch, W.A., Derda, D. \& Kelley, M.R. (1991) Drosophila AP3, a presumptive DNA repair protein, is homologous to human ribosomal associated protein $\mathrm{P} 0$. Nucleic Acids Res. 19, 4297.

8. Frolov, M.V. \& Birchler, J.A. (1998) Mutation in $\mathrm{P} 0$, a dual function ribosomal protein/ apurinic/apyrimidinic endonuclease, modifies gene expression and position effect variegation in Drosophila. Genetics 150, 1487-1495.

9. Hulsey, M., Goldstein, R., Scully, L., Surbeck, W. \& Reichlin, M. (1995) Anti-ribosomal P antibodies in systemic lupus erythematosus: A case-control study correlating hepatic and renal disease. Clin. Immunol. Immunopathol. 74, $252-256$.

\section{Figure 3. Multiple sequence alignment (Clustal W) of P0 proteins.}

HUM, human (accession No. P05388); DRO, Drosophila melanogaster (P19889); NEU, Neurospora crassa (AF361225); CER, Saccharomyces cerevisiae (NP_013444); POM, Schizosaccharomyces pombe (CAA21428); ARA, Arabidopsis thaliana (AAB95286); PLA, Plasmodium falciparum (AAD10140); TRY, Trypanosoma cruzi (P26796); LEI, Leishmania chagasi (L29300). Conserved amino acids are marked with an asterisk, ":" denotes similarity. I and II, indicate conserved clusters of amino acids in the rRNA interacting domain, III, domain responsible for interaction with $\mathrm{P} 1 / \mathrm{P} 2$ proteins, IV, conservative $\mathrm{C}$-terminal domain. 
10. Schijman, A.G., Levitus, G. \& Levin, M.J. (1992) Characterization of the C-terminal region of a Trypanosoma cruzi 38-kDa ribosomal P0 protein that does not react with lupus anti-P autoantibodies. Immunol. Lett. 33, 1520 .

11. Kurup, V. \& Banerjee, B. (2000) Fungal allergens and peptide epitopes. Peptides 21, 589599.

12. Kusuda, M., Yajima, H. \& Inoue, H. (2000) Characterization and expression of a Neurospora crassa ribosomal protein gene, crp-7. Curr. Genet. 37, 119-124.

13. Sambrook, J., Fritsch, E.F. \& Maniatis, T. (1989) Molecular Cloning. A Laboratory Manual. Cold Spring Harbor Laboratory. Cold Spring Harbor NY.

14. Garber, R.C. \& Yoder, C.O. (1983) Isolation of DNA from filamentous fungi and separation into nuclear, mitochondrial, ribosomal, and plasmid components. Anal. Biochem. 135, 416-422.

15. Sodeoka, M., Larson, C.J., Chen, L., LeClair, K.P. \& Verdine, G.L. (1993) Multifunctional plasmid for protein expression by ECPCR. Overproduction of the p50 subunit of NF-kappa-B. Bioorg. Med. Chem. Lett. 3, 10891095.

16. Tchórzewski, M., Boguszewska, A., Abramczyk, D. \& Grankowski, N. (1999) Overexpres- sion in Escherichia coli, purification, and characterization of recombinant $60 \mathrm{~S}$ ribosomal acidic proteins from Saccharomyces cerevisiae. Protein Expr. Purif. 15, 40-47.

17. Laemmli, U.K. (1970) Cleavage of structural proteins during assembly of the head of bacteriophage T4. Nature 277, 680-685.

18. Altschul, S.F., Gish, W., Miller, W., Myers, E.W. \& Lipman, D.J. (1990) Basic local alignment search tool. J. Mol. Biol. 215, 403-410.

19. Thompson, J.D., Higgins, D.G. \& Gibson, T.J. (1994) CLUSTAL W: Improving the sensitivity of progressive multiple sequence alignment through sequence weighting, position-specific gap penalties and weight matrix choice. Nucleic Acids Res. 22, 4673-4680.

20. Rambosek, J. \& Leach, J. (1987) Recombinant DNA in filamentous fungi: Progress and prospects. Crit. Rev. Biotechnol. 6, 357-393.

21. Planta, R.J. \& Mager, W.H. (1998) The list of cytoplasmic ribosomal proteins of Saccharomyces cerevisiae. Yeast 14, 471-477.

22. Santos, C. \& Ballesta, J.P. (1995) The highly conserved protein $\mathrm{P} 0$ carboxyl end is essential for ribosome activity only in the absence of proteins $\mathrm{P} 1$ and P2. J. Biol. Chem. 270, 20608-20614. 